\title{
3 Pautas metodológicas para el análisis sociocognitivo de los LTG y corpus
}

El análisis que presentamos a continuación parte de una contextualización sociopolítica de cada periodo en el que se verificó la reforma educativa que dio lugar a la creación de nuevos libros de texto. En este sentido, para cada generación de libros hemos realizado una investigación del contexto social, político e ideológico de los gobiernos que impulsaron las reformas y controlaron la producción de los libros. Asimismo, nos hemos documentado sobre las características de los planes y programas para primero de primaria surgidos a partir de las reformas, así como de las polémicas que despertó cada generación entre diversas esferas de la sociedad mexicana. Toda esta información es imprescindible para comprender los contenidos de los libros, las estrategias de conceptualización para comunicarlos y las modificaciones que incluso una misma generación de libros ha sufrido. Esta información sociopolítica encabeza cada uno de los capítulos referentes a los LTG.

En cuanto al análisis de los manuales, este consistió en la identificación de los modelos mentales (Lakoff 1989) que conforman el Modelo Cognitivo Idealizado de MEXICANO propuesto por los libros de primer año de primaria. Tales modelos, considerados aquí como las unidades de análisis, fueron elaborados icónica y lingüísticamente a partir de distintas operaciones de conceptualización. Ha sido uno de nuestros objetivos identificar cuáles son estas operaciones que resultan en la formación y fijación del MCI de la IDENTIDAD MEXICANA, así como de los ideologemas mediante los que esta representación se almacena y reproduce.

Para este fin, en una tabla Excel hemos transcrito los extractos de texto o descrito las imágenes donde se observaba un modelo cognitivo. Aunque este es un trabajo de tipo cualitativo, la cuantificación de las veces que aparece un modelo cognitivo o una palabra que abre un espacio mental (por ejemplo, la palabra patria o madre) nos resultó muy productivo, ya que al triangular la información hemos podido constatar los cambios en el énfasis que se le ha dado a los componentes del MCI de IDENTIDAD MEXICANA a través del tiempo e incluso visualizar esta información mediante esquemas radiales como mostramos al final de cada capítulo. En esta línea, hemos considerado como ítem cada uno de los dibujos o palabras que indican las instancias (elaboraciones o instanciaciones)) de un modelo cognitivo. Así, por ejemplo, si en una lectura encontramos la palabra bandera y su imagen (elaboraciones del MCI de PATRIA), contabilizamos 2 ítems. En el caso de la palabra padres hemos optado por contabilizar 2 ítems, uno correspondiente a madre y otra a padre. Esta distinción se debe, por un lado, a que en estos libros 
no se toma en cuenta a las familias homoparentales y, por otro lado, porque las propiedades semánticas que posee la voz padres corresponden a las que poseen en otros ejemplos madre y padre por separado.

Debido a que el corpus fue facilitado por la CONALITEG como imágenes en formato PDF, no fue posible copiar y pegar el texto, sino que se tuvo que transcribir manualmente. Además, ya que los libros presentan muchos dibujos, son antiguos y su tipo de papel hace que el fondo sea de color amarillento-marrón (sobre todo las tres primeras generaciones), no fue posible encontrar un programa informático que leyera de manera óptima las palabras y las pudiera contar, de tal suerte que el cómputo de palabras e imágenes se tuvo que hacer también de manera manual.

\subsection{El corpus}

Los LTG son propiedad de la nación mexicana y está prohibida su venta. Por esta razón el corpus fue consultado directamente en las oficinas de la Comisión Nacional de Libros de Texto Gratuitos (CONALITEG), donde fueron facilitados de manera digital al inicio de esta investigación. Sin embargo, a partir del 2018 estos materiales y toda la colección de libros de texto gratuitos editados de 1960 hasta la segunda reimpresión en 2018 han sido puestos a disposición del público de manera digital. ${ }^{1}$ Este hecho nos permitió no solo contar con un corpus, sino tener un acervo completo de libros. Además, tal digitalización nos ha resultado sumamente útil, ya que solo así nos pudimos percatar de modificaciones sobre las cuales no habíamos encontrado referencia alguna en toda la bibliografía consultada y que documentamos por vez primera en este trabajo.

Para el estudio de la primera generación de libros hemos tomado en consideración los materiales que los niños recibieron en el primer grado de 1960 hasta 1972, a saber, el libro de lectura Mi libro de primer año (a partir de aquí LL), Mi cuaderno de trabajo de primer año (a partir de aquí CT), así como el Instructivo para el maestro (a partir de aquí IM).

La decisión de considerar el manual del maestro se debió al hecho de que la última parte del CT, titulada "Civismo e Historia”, comprende una serie de viñetas en las que se presenta la historia de México mediante diferentes pasajes de la vida de algunos héroes nacionales. Esta parte carece de texto, sin embargo, en el

1 Todas las generaciones de libros (con excepción de los manuales para el maestro, los libros de historia de 1992 y los libros en lenguas indígenas) se pueden consultar libremente a través del siguiente enlace: https://historico.conaliteg.gob.mx/content/common/consulta-libros-gb/. 
IM se explicita que estos materiales son proporcionados para: "[. . . ] fomentar el culto a los símbolos de la patria, el respeto a la tradición y a la cultura de México” y se advierte que:

Estos últimos conocimientos se dan en forma de historietas mudas, las cuales debe aprovechar el maestro realizando diversos ejercicios hasta grabar en la mente del alumno la significación que para nuestra patria tienen (IM p. 52).

En el IM, por cada historieta aparece un pequeño texto que destaca los acontecimientos más relevantes de la vida de estos personajes. Tales acontecimientos corresponden a las escenas dibujadas en el CT. Por esta razón, siguiendo las instrucciones dadas a los profesores, es muy posible que estos se apoyaran en la lectura de los textos al momento de revisar con los niños esta parte de su CT, o bien que repitieran las palabras propuestas por los productores textuales al ser expresamente consideradas como la información esencial que fomentaría el culto y el respeto a la cultura mexicana.
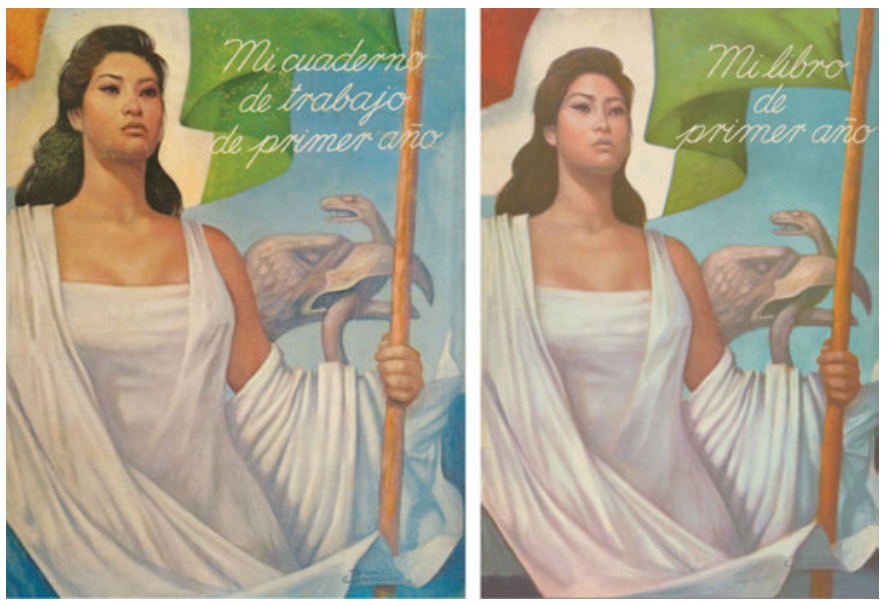

Fig. 1: Primera generación de LTG de primer año (1960-1972): “los libros de la Patria”.

Varios estudiosos de los LTG (Villa Lever 1988, 2011; Torres Barreto 2007, entre otros) han establecido las generaciones de libros de texto gratuitos de acuerdo a las reformas educativas que el gobierno mexicano ha llevado a cabo y a partir de las cuales se han modificado los contenidos de los materiales. Como estos autores, consideraremos dentro de la segunda generación de LTG los manuales publicados en 1972 a raíz de la segunda reforma educativa. Para estos estudiosos, la segunda generación de LTG comprende todas las reimpresiones y edicio- 
nes que se realizaron hasta la nueva reforma en 1994. En contraste con ellos, nosotros consideraremos una tercera generación aparecida a la mitad de este periodo de veinte años (1972-1994), ya que en 1978 hubo una revisión de los libros que implicó la modificación total de los manuales de primero y segundo grados. Aunque los objetivos del proyecto de 1972 siguieron vigentes hasta 1994 y las modificaciones que se hicieron se centraron solo en los métodos de enseñanza (González Pedrero 1982), los cambios a nivel visual y temático son muy significativos, ya que construyen una nueva concepción de la identidad mexicana. Por lo anterior, consideramos como segunda generación de LTG los manuales publicados entre 1972 y $1982 .^{2}$

A diferencia de la generación de los sesenta, en esta generación las materias no fueron integradas en un solo libro, sino que se editó un libro por materia. De tal suerte que, a partir del ciclo escolar 1972-1973, los niños de primero recibieron 5 manuales: Matemáticas, Primer Grado; Español Ejercicios, Primer Grado; Español Recortable, Primer Grado; Ciencias Sociales, Primer Grado; Ciencias Naturales, Primer Grado. El corpus que hemos considerado para nuestro análisis está compuesto por todos estos manuales con excepción del de matemáticas. Esto se debe a que usamos el mismo criterio de selección que en la generación precedente. Esto es, analizamos las cuatro áreas temáticas y excluimos la parte de matemáticas ya que no aporta elementos indicativos de identidad mexicana.

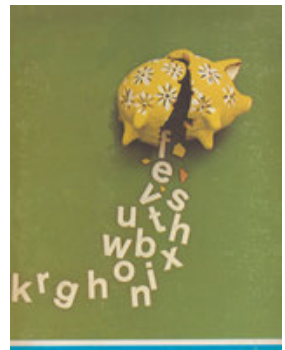

espuniol

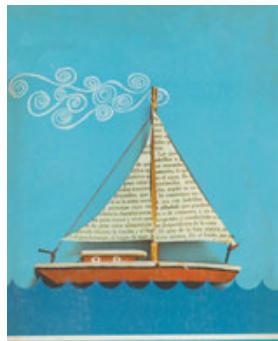

espuiiol
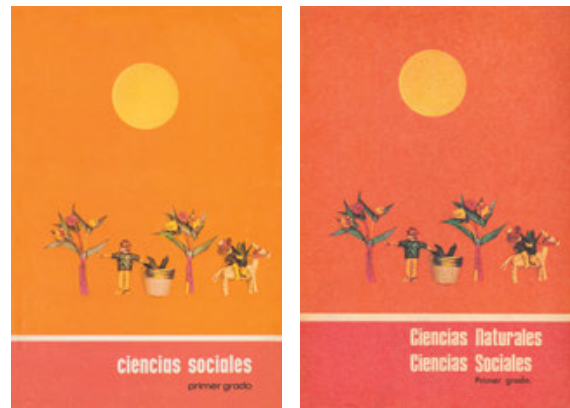

Fig. 2: Segunda generación de LTG de primer año (1972-1980): “los libros de los juguetes”.

Para el análisis de la tercera generación tomamos en cuenta los cuatro manuales designados al primer grado de primaria que circularon entre 1980 y 1993: $M i$ libro de primero. Parte I; Mi libro de primero. Parte II; Mi libro de primero recor-

2 Raúl Ávila (2011, p. 385) coautor de los libros de Español de 1972 y coordinador general de los libros editados a partir de 1980, también se refiere a los libros de los setenta como la segunda generación y a los de los ochenta como la tercera. 
table. Parte I y Mi libro de primero recortable. Parte II. Los libros de la tercera generación cambiaron sus portadas en 1989: los manuales con las portadas de niños fueron sustituidos por los llamados por el equipo de la CONALITEG "los libros de los pintores”. Sin embargo, no hubo cambios internos, lo que pudimos comprobar revisando y comparando los cuatro volúmenes.
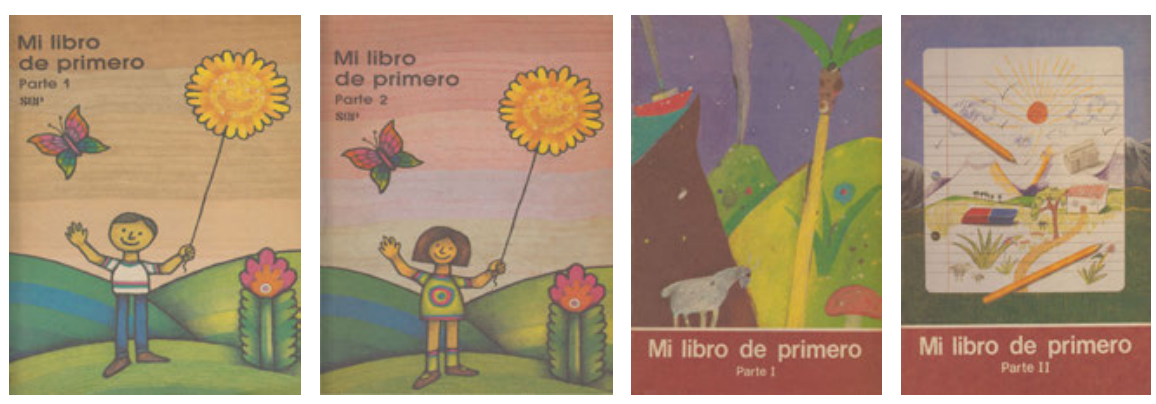

Fig. 3: Tercera generación de LTG de primer año (1980-1993): los libros integrados.

La cuarta y última generación de LTG que analizamos fue puesta en circulación en 1993 tras la reforma educativa. Sin embargo, gracias al Catálogo Histórico de Libros de Texto Gratuitos disponible en línea, nos percatamos de que en 1997 el libro de Español, su correlativo recortable y el libro de lecturas fueron sustituidos por libros totalmente diferentes. Para esta investigación tomaremos en cuenta los manuales con los que los escolares estudiaron el primer año de primaria a partir de 1997. Esta decisión se tomó debido a que, por un lado, los tres libros de Español que fueron sustituidos retoman muchos de los textos ${ }^{3}$ e imágenes de los libros de los ochenta, como se advierte en la introducción del libro de lecturas (p. 3):

Para la asignatura de Español se utilizará el libro Español. Primer grado, el libro Español. Primer grado. Recortable y el libro Español. Lecturas. Primer grado, elaborados por esta Secretaría.

3 Efectivamente, el libro de lecturas conserva 32 lecturas de las 62 repartidas en los dos manuales de los ochenta. Algunas de las lecturas omitidas, sin embargo, se encuentran en el libro de Español. Primer grado (EP). Es el caso de los textos sobre los personajes históricos (Miguel Hidalgo y Nezahualcóyotl) y las tituladas "Segador", "Yo ayudo a mi papá" y "Caminito de la escuela”. Cabe mencionar que el manual Español. Primer grado editado e reimpreso de 1993 a 1997 no está a disposición en el catálogo en línea de la CONALITEG. Hemos podido tener acceso a él solo mediante fotografías que tomamos de este en 2015 (cuando aún no estaban en línea) en la biblioteca del hoy desaparecido Centro de Estudios Educativos (Ciudad de México). 
Español. Lecturas. Primer grado conserva la mayoría de los textos que constituían el apartado de lecturas de Mi libro de primero, partes I y II, que fue utilizado hasta el ciclo escolar 1992-93.

Por otro lado, aunque los revisamos, no consideramos como objeto de análisis los manuales de 1993 ya que estos solo estuvieron en circulación cuatro años. En cambio, los que los sustituyeron fueron utilizados desde el ciclo 1997-1998 hasta el ciclo 2008-2009 tras una nueva reforma educativa. En suma, la mayor distancia con respecto a los manuales de la generación anterior nos permite apreciar mejor los cambios en la concepción identitaria, y la larga vida de estos libros nos ofreció mayor facilidad para encontrar a los informantes a partir de los cuales realizamos la parte empírica de esta investigación. Siguiendo la misma lógica con que analizamos las generaciones anteriores, de esta consideraremos los manuales que recibían los estudiantes de primer grado con excepción de los dos libros de matemáticas. Es decir que tomaremos en consideración cinco libros: 1) Libro Integrado. Primer grado; 2) Libro Integrado. Primer grado. Recortable; 3) Español. Primer grado. Actividades; 4) Español. Primer grado. Recortable y 5) Español. Lecturas. Primer grado.
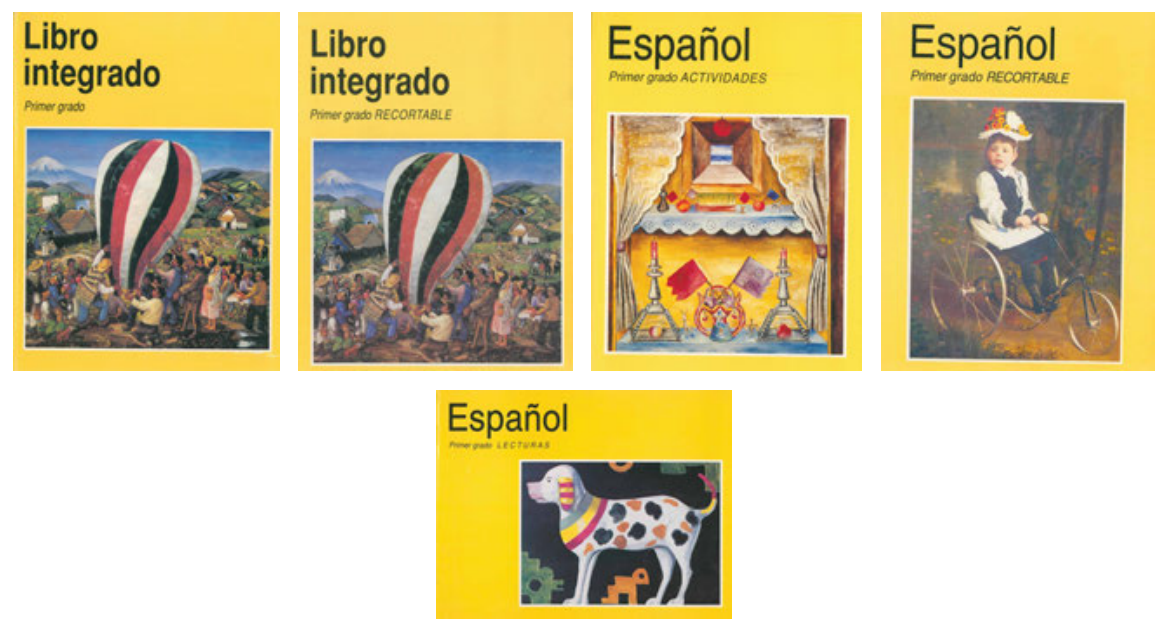

Fig. 4: Cuarta generación de LTG de primer año (1997-2008): los libros del nuevo milenio. 